\title{
CHCIWOŚĆ CZY KULTURA CHCIWOŚCI? DYSKUSJE NAD ŹRÓDŁAMI KRYZYSU FINANSOWEGO
}

ABSTRACT. Sójka Jacek, Chciwość czy kultura chciwości? Dyskusje nad źródłami kryzysu finansowego [Greed or culture of greed? Debates on the sources of the financial crisis] edited by W. Banach „Człowiek i Społeczeństwo", vol. XXXVIII, Poznań 2014, pp. 165-185, Adam Mickiewicz University Press. ISBN 978-83-232-2791-5. ISSN 0239-3271.

Greed as an excessive desire for wealth returned as a popular catchword after the fall of Lehman Brothers in 2008. Because it was only the beginning of the global financial crisis, the notion of greed has been present in public discourse since that time. A legitimate question arises to what extent it could have really contributed to economic instability. But equally important are the questions of semantics. Of course, the notion of greed has its ancient roots and has been always present in religious writings and philosophical works, but today's use of this notion requires an analysis. What do we mean when we say "greed"? What do we want to achieve (pragmatic aspect), and what are the motives of those writers who include greed into their diagnoses of economic downturns?

The major claim of this article is that greed as an individual desire cannot be a proper explanation of the crisis. More important factors are the political and social mechanisms, esp. the role of the regulators of the mortgage industry in the US. Sociological analysis of that industry, which triggered the whole crisis, shows that the crisis was not an example of the excess of the free market and deregulation but rather something created by the politicians. Paradoxically an analysis of the systemic social and political factors which had led to the crisis allow us to reflect on greed as a notion which is a part of the so-called culture of excess - characterized, among others, by the process of the "democratization of desires".

Jacek Sójka, Uniwersytet im. Adama Mickiewicza w Poznaniu, Wydział Nauk Społecznych, Instytut Kulturoznawstwa, Zakład Etyki Gospodarczej, ul. Szamarzewskiego 89a, 60-568 Poznań, Poland.

\section{WSTĘP}

Sporo pisano i mówiono o chciwości w związku z niedawnym kryzysem finansowym. Chciwość miałaby być nawet główną przyczyną upadku Wall Street, który dał początek globalnym zawirowaniom na rynkach finansowych. Papież Benedykt oraz Dalajlama, filozof Alasdair MacIntyre oraz aktywista konsumencki Ralph Nader, dziennikarze, ekonomiści i literaci zgodnym chórem potępiali tę ludzką przywarę, a jednocześnie, nierzadko, 
sam kapitalizm jako podstawową przyczynę jej ujawniania się. Myślę, że jest to dobra okazja do zastanowienia się nad sensem tego słowa i powodami jego używania w tym kontekście. Podkreślę, iż chodzi mi tutaj o sens tego wyrażenia oraz użytek z niego robiony, nie zaś o istotę ludzkich pragnień i żądzy, o których nie da się zbyt wiele powiedzieć w oderwaniu od historyczno-kulturowych kontekstów. Nawet badania empiryczne będą dotyczyły konkretnej próby i konkretnych pytań zadanych ludziom i nie dadzą nam esencjalnego wglądu w istotę chciwości. Mówiąc o chciwości na przykład w kontekście średniowiecznej kultury, odnosimy się nie do ludzkich, ponadczasowych przywar, lecz do pewnego dyskursu w znaczeniu M. Foucaulta przejętym przez studia kulturowe, jako czegoś jednoczącego język i praktykę 1 .

Nie chciałbym też zmagać się niepotrzebnie ze starym problemem, co powoduje ludźmi: pasje i namiętności czy też wzorce i instytucje społeczne. Oczywiście kulturoznawca wskaże na ponadjednostkowe systemy przekonań, które ukierunkowują indywidualne działania, nawet jeśli towarzyszą im silne emocje. Można jednak zastanawiać się, czy ta ponadjednostkowa sfera nie zawiera w sobie takich wartości i norm, które nie tylko rozgrzeszają jednostkę z ulegania "niezdrowym” popędom (tzn. nieakceptowanym w świetle wcześniejszych, usankcjonowanych przez tradycję norm), lecz wręcz zachęcają do przekraczania granic tradycyjnie rozumianej przyzwoitości czy racjonalności. Przykładem mogą być tzw. sporty ekstremalne uprawiane przez amatorów, do czego zachętę można odnaleźć w kulturze masowej i medialnym kulcie ryzyka oraz poszukiwania przygody za wszelką cenę. Być może podobny mechanizm funkcjonuje w sferze gospodarczej, na rynkach finansowych. W kulturze danej branży zdaje się tkwić pewien bodziec czy zachęta do zachowań, które - po fakcie, gdy znane są już wszystkie okoliczności uważa się za przejaw tego, co potocznie nazywamy chciwością.

Brady Willett twierdzi, że to narastająca fala działań nielegalnych i nieracjonalnych decyzji inwestorów oraz zaniedbań regulatorów doprowadziła do kryzysu 2007-2009. Powoływanie się na chciwość byłoby wynikiem ludzkiej skłonności do "antropomorfizowania ducha kapitalizmu”. Skomplikowane mechanizmy gospodarcze nabierają wówczas cech ludzkich i stają się zrozumiałe ${ }^{2}$. Niemniej niedomagania tych mechanizmów wciąż są wyzwaniem dla nauk społecznych, a problem "chciwości” jest raczej zachętą do dociekań aniżeli ostateczną diagnozą.

${ }^{1}$ C. Barker, Studia kulturowe. Teoria i praktyka, Wydawnictwo Uniwersytetu Jagiellońskiego, Kraków 2005, s. 115.

2 B. Willett, Financial Crisis Blaming the Culture of Greed?, "The Market Oracle” 7.04.2009, http:/www.marketoracle.co.uk [dostęp: 1.01.2014]. 


\section{ZNACZENIA TERMINU}

Interesują mnie - przypomnę - znaczenia słów odzwierciedlające historyczne uwarunkowania, czyli to, co mamy na myśli, kwalifikując pewne zachowania jako przejaw chciwości. Pojęcie chciwości, oczywiście, odnosi się do określonych ludzkich przywar, ale jednocześnie jest usytuowane w systemie innych pojęć i jego sens kształtowany jest przez kontekst kulturowy. (Abstrahuję $\mathrm{w}$ tym momencie od usytuowania pojęć $\mathrm{w}$ obrębie praktyki i od problemu uchwytnego efektu ich używania, czyli od ich miejsca w ramach dyskursu - w szczególności wykluczającego).

A zatem "chciwość”, według słownika Witolda Doroszewskiego, to „bycie chciwym, pragnienie, pożądanie czego; pożądliwość, łapczywość, łakomstwo, zachłanność: A po cóż pożerać ogromne kęsy? Toć to chciwość i żarłoctwo" 3 . "Chciwość" w języku polskim odnosi się nie tylko do pragnienia posiadania dóbr materialnych, ale do wszelkiego rodzaju zachłanności, w szczególności do łakomstwa i wszelkich jego skutków. Ten niefinansowy wymiar chciwości sprawia, że w pewnych kontekstach wyrażenie to może mieć konotację nad wyraz pozytywną. "Archanielskie bledną twarze, gdy na słońce się ukaże chciwość życia i zawziętość" - pisał Adam Asnyk. Jan Lam wspominał: „Pożerałem z chciwością, dość rzadką w tym wieku, opisy podróży, powiastki i dzieła traktujące o historii narodów"4.

Podobne znaczenie ma słowo "greed” w języku angielskim. „1. nadmierna konsumpcja lub pragnienie jedzenia; żarłoczność. 2. nadmierne pożądanie, np. bogactwa lub władzy"5. Kontekst stołu jest tutaj nawet bardziej wyeksponowany. W sumie, w znaczeniu przenośnym, można być chciwym w stosunku do bardzo wielu pożytecznych rzeczy, takich jak wiedza, uznanie innych ludzi, miłość. O tym właśnie mówił Ivan Boesky, słynny w latach osiemdziesiątych ubiegłego wieku bankier inwestycyjny, w swoim przemówieniu do studentów zarządzania podczas uroczystości absolutoryjnej. „Możecie być chciwi, a jednak czuć się z tym dobrze”6. Problemem było jednak to, o jakich przejawach chciwości mógł był wówczas myśleć. Kilka miesięcy później został bowiem skazany na trzy lata więzienia za oszustwa giełdowe.

3 Stownik jezzyka polskiego, t. 1, red. W. Doroszewski, Państwowe Wydawnictwo „Wiedza Powszechna", Warszawa 1958, s. 844; przykład użycia słowa zaczerpnięty z: J. Iwaszkiewicz, Nowa miłość, Czytelnik, Warszawa 1947, s. 92.

${ }^{4}$ A. Asnyk, Poezje, t. 1, Nasza Księgarnia, Warszawa 1938, s. 237; J. Lam, Wybór pism, t. 1, Głowy do pozłoty, Redakcja Gazety Polskiej, Warszawa 1899, s. 13, cyt. za: Stownik..., s. 844.

5 Collins English Dictionary, Harper Collins Publisher, Glasgow 1991, s. 679.

6 B. Greene, Million Idea. Use Greed for Good, "Chicago Tribune" 15.12.1986, http://articles.chicagotrubune.com [dostęp: 15.05.2014]. 
Atmosferę na Wall Street $\mathrm{w}$ tym okresie bardzo realistycznie odmalował Oliver Stone w znanym filmie z 1987 roku. Jeden z głównych bohaterów, wzorowany zresztą na Boeskym, rozwija jego myśl w słynnym przemówieniu do akcjonariuszy Teldar Paper: „Chciwość - a nie mamy lepszego słowa jest dobra. Chciwość ma rację. Chciwość jest skuteczna. Chciwość oczyszcza, porządkuje, wyraża istotę ducha ewolucji. Chciwość we wszystkich jej przejawach, w odniesieniu do życia, pieniędzy, miłości, wiedzy, była zawsze oznaką wzlotu gatunku ludzkiego. A zatem chciwość - zapamiętajcie moje słowa - nie tylko uratuje Teldar Paper, lecz także tę inną niedomagającą firmę zwaną Stanami Zjednoczonymi"7. Cytat ten powraca w bardzo wielu opracowaniach poświęconych chciwości; nie mogło go zabraknąć i tutaj. Gordon Gekko wypowiadający pochwałę chciwości - podobnie jak Boesky kończy w więzieniu. Duch ewolucji, nawet jeśli to społeczny darwinizm miałby go wyrażać najlepiej, nie toleruje oszustwa. To przekonanie rozstrzyga wszelkie dylematy semantyczne. Można być chciwym życia, wiedzy, przygody, miłości, lecz problemem Wall Street $\mathrm{w}$ tamtych latach był nie tylko nadmiar pożądania szybkich zysków, łatwych prowizji, wysokich premii i jeszcze wyższych odpraw, gdy już trzeba było rozstać się z firmą, lecz przede wszystkim działania niezgodne z prawem (o czym sami zainteresowani dobrze wiedzieli).

Gordon Gekko nie jest ani filozofem, ani teologiem, nie proponuje żadnej wizji świata; słowa, które wypowiada, podporządkowane są podejmowanym działaniom - przez niego i jemu podobnych8. "Pożądanie”, „żądza”, "wzrost" funkcjonują tutaj w ramach określonego dyskursu. Język społecznego darwinizmu, przywoływana przez Gekka historia gospodarki amerykańskiej (Mellon i Rockefeller) oraz wskazanie na kłopoty źle zarządzanej firmy - wszystko to służy perswazji i zjednywaniu sobie akcjonariuszy podczas walnego zgromadzenia. Zawołanie „chciwość jest dobra” znaczy mniej więcej: "bądźmy jak kapitanowie przemysłu z początku wieku”, "zaryzykujmy", ,znajdźmy w sobie zapomniane cnoty pionierów”.

\section{2. ŚREDNIOWIECZNA WIZJA ŚWIATA}

Znaczenia słów nie istnieją bez kontekstu. Mówiąc o chciwości, nie sposób abstrahować od antycznej historii samego pojęcia i jego uwikłania $\mathrm{w}$ konteksty religijne. We wszystkich wielkich systemach religijnych pro-

7 Wall Street, reż. O. Stone, scen. S. Weiser, O. Stone, Twentieth Century Fox, 1987.

${ }^{8}$ Dyskurs i ideologia są sobie bliskie. 
blem ten się pojawia. Czy to będzie hinduizm czy chrześcijaństwo, chciwość uważana jest za jeden z najpoważniejszych grzechów ${ }^{9}$. Gdy jednak myślimy o "duchu kapitalizmu”, tradycja judeochrześcijańska jest dla nas zasadnicza.

Średniowieczna nauka o grzechu z dzisiejszej kulturoznawczej perspektywy być może widziana jako kulturowe konstruowanie moralności. Mniej ważne są aspekty teologiczne, bowiem istotniejsze jest to, co Richard Newhauser nazywa formułowaniem społecznie akceptowanych form pożądania (desire) czy też socjalizacją pożądania ${ }^{10}$. W pierwszej kolejności nakazy te adresowane były do przedstawicieli życia zakonnego, bowiem namiętności jako podszepty demonów odciągały mnichów od modlitwy i uniemożliwiały osiągnięcie wewnętrznej wolności od wszelkich pasji (apatheia). Z czasem jednak krąg adresatów poszerza się, a nauka o grzechu i cnocie staje się podstawą „świeckiej” moralności ${ }^{11}$.

Zapytać jednak należy, dlaczego właśnie chciwość (avaritia) była tym najcięższym grzechem. Grzech ten powinien być widziany na tle licznych wątków charakterystycznych dla chrześcijańskiej wizji świata: odchodzenia od pierwotnej równości wszystkich ludzi, podziału dóbr w życiu doczesnym oraz perspektywy zbawienia. W odróżnieniu od reguł życia zakonnego nie wymagano nadmiernej ascezy od wszystkich. Wczesnochrześcijańskie poglądy ewoluowały i z czasem bogactwo przestało być przeszkodą w osiągnięciu życia wiecznego. Niemniej obowiązkiem bogatych było dzielenie się $\mathrm{z}$ biednymi. Już we wczesnej literaturze tego okresu pojawia się przypowieść o wiązie i winorośli, która szkicuje pewien ideał porządku społecznego. Biedni i bogaci potrzebują siebie nawzajem: bogaci wspomagają biednych - ci zaś rewanżują się modlitwą, której bogaci potrzebują bardziej niż ktokolwiek. Winorośl - aby mogła wydać wartościowy owoc - potrzebuje wiązu, po którym pnie się w górę ${ }^{12}$.

W średniowieczu gospodarka była widziana jako gra o sumie zerowej. Bogactwo jednych oznaczało ubóstwo drugich, tak więc problem opanowywania żądzy bogactwa wydawał się podstawą porządku społecznego (zwłaszcza w perspektywie eschatologicznej). Problem chciwości potępiany był ostrzej w pismach Ojców Kościoła szczególnie w okresach kryzysowych (np. w III wieku n.e.) ${ }^{13}$. Trudno oprzeć się wrażeniu, że tak się dzieje przez

${ }_{9}$ P. Tickle, Greed. The Seven Deadly Sins, Oxford University Press, Oxford 2004, s. 12.

10 R. Newhauser, The Seven Deadly Sins as Cultural Constructions in the Middle Ages, www.trinity.edu/rnewhaus/outline.html [dostęp: 1.03.2014].

11 Ibidem; ta podstawa „świeckiej” moralności, zważywszy na jej funkcję socjalizacyjną, może być ujmowana jako forma dyskursu.

12 R. Newhauser, The Early History of Greed. The Sin of Avarice in Early Medieval Thought and Literature, Cambridge University Press, Cambridge 2000, s. 5.

${ }^{13}$ Ibidem, s. 22. 
wszystkie wieki. Gdy społeczeństwo biednieje, szuka się tych, którzy „zabrali" to, czego ludziom teraz brakuje. I nie ma znaczenia, jakich słów używa się w tym kontekście. Słowa i działania składają się na dyskurs wykluczający: winowajcy powinni zostać wykluczeni ze społeczeństwa i znaleźć się na przykład w piekle niczym średniowieczni lichwiarze (ale i dla nich $\mathrm{w}$ okresie renesansu znajdzie się lepsze miejsce - w czyśćcu).

Do dzisiaj chrześcijańska wizja świata opiera się - jak pisał Jack Mahoney - na tych "aspektach wiary, które zajmują się stworzeniem, grzechem, zbawieniem oraz doskonałościa, a także ich etycznymi implikacjami". Przedsiębiorczość jednostek nie jest już jednak „podejrzana”, jeżeli oczywiście oznacza współpracę z Bogiem „w twórczym dziele pomnażania zasobów ziemskich i ludzkich we wspólnym interesie nas wszystkich". Przedsiębiorczość oznacza więc obietnicę polepszenia bytowania ludzi, lecz jednocześnie budzi zniecierpliwienie, jeśli niedostatecznie realizuje ideał wspólnego dobra. Istnieje zatem $\mathrm{w}$ tej wizji świata trwałe moralne napięcie "pomiędzy Bożym celem współpracy ludzi w dziele pomnażania ziemskich zasobów $\mathrm{w}$ interesie dobrobytu wszystkich a historycznie objawiającą się ludzką skłonnością do zaspokajania własnych interesów kosztem innych i przez to zniekształcania ostatecznego celu Bożego stworzenia"14.

\section{GOSPODARKA NOWOŻYTNA}

Gospodarka tego okresu oznaczała nowe spojrzenie na problem wytwarzania i dystrybucji dóbr. W przeciwieństwie do agrarnej kultury średniowiecza nie chodziło już o sprawiedliwy podział plonów i potępianie tych, którzy gotowi byli zagarnąć więcej kosztem swoich bliźnich. "Chciwość" przestaje się pojawiać jako zagrożenie ładu społecznego i - w sumie - apel o wykluczenie kogokolwiek. Raczej - w zgodzie z ówczesnymi osiągnięciami nauki - szukano mechanizmów, które napędzały gospodarkę. Społeczeństwo składać się miało z względnie autonomicznych jednostek, a ład społeczny w tej sytuacji mógł się opierać jedynie na serii kontraktów zawieranych przez te jednostki, które kierowały się przede wszystkim tzw. interesem własnym. Rolą władcy czy też rządu było sprawne koordynowanie i kontrolowanie tak rozumianej dynamiki społecznej. Interes własny był tym czynnikiem, który rozpoznawano jako siłę sprawczą rozwoju społeczeństwa, przy czym to rozpoznanie inspirowane było mechaniką Newtona jako wzorem naukowego podejścia.

${ }^{14}$ J. Mahoney, Chrześcijaństwo a etyka przedsiębiorczości, [w:] Etyka w biznesie, red. P.M. Minus, Wydawnictwo Naukowe PWN, Warszawa 1995, s. 110-111. 
Pytanie, które w kontekście tych rozważań nad chciwością należy postawić, brzmi: czy rację mają ci badacze, którzy interes własny uznają za nowożytną formę chciwości. Gdyby tak było, chciwość rzeczywiście byłaby przyczyną wielu kryzysów gospodarczych. Czy zatem „interes własny” jest tylko nową nazwą starego grzechu? Czy też pomimo pewnych podobieństw przynależy do całkiem innego systemu myślowego, m.in. pozbawionego napięcia pomiędzy grzechem zachłanności a cnotą umiarkowania? Twierdziłbym, iż należy ono do całkiem nowego dyskursu i nowego obrazu świata.

Tradycyjnie już cytuje się Adama Smitha, aby wykazać, że szkicuje on wizję społeczeństwa, w którym - za sprawą niewidzialnej ręki rynku - egoistycznie pojęte interesy stają się zbiorową korzyścią. Rzeźnik, piwowar i piekarz oferują nam swoje produkty, mając na względzie swój własny interes. Bardzo często poprzestaje się na cytowaniu tego fragmentu znanego dzieła Smitha, uznając, iż oto znamy całą prawdę: Smith pochwala egoizm i nie zauważa problemu dobra wspólnego (podobnie jak jego współcześni wyznawcy).

Sprawa jest jednak bardziej skomplikowana, a całe dzieło Smitha nie da się sprowadzić do tego cytatu, skądinąd jednego z najczęściej przywoływanych w literaturze światowej. Smith bowiem dopuszczał możliwość niezrozumienia własnego interesu i na przykład dążenia do bogactwa w celu zapewnienia sobie spokoju, który można przecież osiągnąć bez nadmiernej zamożności. Wynikałoby z tego, że człowiek rzeczywiście (jak powiedziałby esencjalista) jest stworzeniem niedoskonałym, niemniej tego typu złudzenia sprawiają, iż - niejako wbrew sobie - pracujemy więcej, a to przyczynia się do ogólnego postępu ${ }^{15}$. Pytanie podstawowe brzmi jednak, czy interes własny miałby być formą tego, co kiedyś nazywano chciwością. Jak uważa znawca twórczości Smitha, Jonathan B. Wight, jeżeli chciwość oznacza nadmierne pożądanie bogactwa lub czegokolwiek, to akurat Adam Smith byłby pierwszym myślicielem, który potępił taką postawę jako prowadzącą do utraty równowagi mentalnej i kontroli nad samą sobą. Przede wszystkim jednak nie zgadzał się na zaspokajanie własnych potrzeb kosztem innych ludzi, na osiąganie sukcesu z pogwałceniem zasad moralnych. Miłość własna - oczywiście - prowadzić może do przedkładania korzyści jednostki nad dobro wielu ludzi, ale nie to było postulatem, lub choćby założeniem, filozofii Smitha. Jego Teoria uczuć moralnych o tym najlepiej świadczy. Tak więc dla Smitha „interes własny oznacza szczegółowy namysł nad własnymi korzyściami i własnym bezpieczeństwem w chwili podejmowania decyzji. Chci-

15 J.B. Wight, Adam Smith and Greed, "Journal of Private Enterprise” 2005, vol. XIX, Fall, s. 50 . 
wość, przeciwnie, oznacza $\mathrm{w}$ takiej sytuacji branie pod uwagę jedynie własnego, wąsko rozumianego, interesu, bez względu na potrzeby i prawa innych osób"16.

Warto zatem wnikliwiej czytać prace Smitha, a nawet dokładniej przyjrzeć się temu najczęściej przywoływanemu fragmentowi Bogactwa narodów. Pierwsze zdanie mówi, że to nie dobroczynność decyduje o skierowanej do nas ofercie rzeźnika, piwowara i piekarza, lecz ich własny interes. Drugie zaś, iż my - jako klienci - nie zwracamy się (nie apelujemy) do ich poczucia wspólnoty z wszystkimi ludźmi i nie opowiadamy im o naszych potrzebach, lecz liczymy na ich zainteresowanie własnym zyskiem: przychodzę do ciebie, gdyż wiem, że chcesz zarobić na tym, czego ja akurat potrzebuję${ }^{17}$. Oni potrzebują pieniędzy, my zaś - ich towarów. Tak więc potrzeba zaspokojenia własnych potrzeb jest podstawą wymiany i o tym mówi ten cytat. Jak podkreśla Amartya Sen, oprócz problemu wymiany istnieje jeszcze kwestia produkcji i podziału, których słynny cytat Smitha nie dotyczy. Sam autor, zwłaszcza w Teorii uczuć moralnych, opowiadał się za poczuciem wspólnoty z innymi ludźmi, wspaniałomyślności i obywatelskości jako podstawach gospodarki ${ }^{18}$.

Krótko mówiąc, nie ma sensu twierdzenie, że interes własny jest tym samym co chciwość. Chodzi bowiem o różne wizje świata i różne dyskursy. Po pierwsze, Adam Smith nie tak to ujmował, a po drugie, pojęcie chciwości związane jest z określonym systemem pojęć (w szczególności z chrześcijańską nauką o grzechu), zaś interes własny dotyczy motywacji tych, którzy decydują się na transakcje gospodarcze, naturalnie korzystne dla siebie (co było przecież ich celem), ale jednocześnie korzystne dla drugiej strony. Oczywiście zawsze można twierdzić, iż interes własny to inna, współczesna forma chciwości, lecz stwierdzenie to nie ma większego sensu, a poza wszystkim obciążone jest grzechem esencjalizmu. To, co nazywa się od czasów oświecenia interesem własnym, odnosi się do motywacji jednostki, dowartościowanej przez nowożytny, zachodni światopogląd, zaś chciwość rozumiana była jako grzech i słabość i piętnowana przez wiele religii z powodu społecznie destrukcyjnego jej charakteru.

Można oczywiście twierdzić, że nowożytne pojmowanie indywidualnych motywacji celowo zafałszowuje grzeszne pragnienia jednostek, nie-

16 Ibidem, s. 51.

17 „We address ourselves, not to their humanity but to their self-love, and never talk to them of our own necessities but of their advantages", A. Smith, An Inquiry Into the Nature and Causes of the Wealth of Nations, [w:] Glasgow Edition of the Works and Correspondence of Adam Smith, eds R.H. Campbell, A.S. Skinner, Liberty Press, Indianapolis 1981, s. 26-27; cyt. za: J.B. Wight, op. cit., s. 49.

18 A. Sen, Czy pojęcie etyki biznesu ma sens ekonomiczny?, [w:] Etyka..., s. 61. 
mniej trudniej byłoby to wykazać (a w szczególności ową celowość), opierając się na materiale historycznym. W związku z tym trudno zgodzić się z A.F. Robertsonem, który twierdzi, iż akademicy wymyślili „interes własny” czy też "wybór racjonalny”, aby tolerować chciwość, przez co tego typu decyzja terminologiczna ma oczywisty charakter moralny. Robertson pisze o interesie własnym jako forgiving notion, czyli jako o usprawiedliwieniu moralnym egoizmu jednostki ${ }^{19}$. Czy ma rację? Gdyby tak było, oznaczałoby to tylko jedno: powstał system gospodarczy oparty na negatywnych cechach jednostek, oparty też na zakłamywaniu swojej własnej natury, na jakimś ideologicznym zafałszowaniu, czyli ukryciu podstawowego mechanizmu. Skąd jednak mielibyśmy wiedzieć, jaka jest natura ludzka? „Interes własny" należy do nowego typu dyskursu. Nie służy już socjalizowaniu popędów, lecz jest wyrazem światopoglądu oświeceniowego i wiary w możliwość odkrycia podstawowych mechanizmów w każdej nieomal dziedzinie życia.

\section{4. „CHCIWOŚĆ” I KRYZYS}

Co zawiodło w globalnej gospodarce, która pod koniec ubiegłego dziesięciolecia pogrążyła się w kryzysie? Czy chciwość (jakkolwiek rozumiana) jest tu mechanizmem podstawowym? W tym momencie właśnie należałoby się przyjrzeć tym wszystkim mechanizmom, które mogły mieć znaczenie. Hansen i Movahedi piszą o „micie indywidualnej chciwości” i przypominają Millsa, który przestrzegał przed tłumaczeniem społecznych zjawisk - problemami jednostek. Wskazują raczej na fakt, że chciwość może być pochodną strukturalnego problemu, który sprawia, iż wszelki brak zachłanności mógłby być traktowany jako oznaka słabości ${ }^{20}$.

Nie tyle chodzi mi tutaj o tradycyjną dyskusję dotyczącą tego, czy cechy jednostek decydują o zjawiskach społecznych czy odwrotnie (kulturoznawcza analiza $z$ natury rzeczy jest antyindywidualistyczna), ile przede wszystkim o to, że ewentualne przyznawanie prymatu pragnieniom i cechom jednostek pragnienia te przedstawia esencjalistycznie jako stale obecne wyposażenie istot ludzkich, niezależne od historii i jakiegokolwiek schematu pojęciowego. Dlatego zastanawiamy się raczej nad tym, co znaczy „chciwość” dzisiaj, a w szczególności co znaczy w odniesieniu do niedawnego kryzysu. Innymi s. 14.

19 A.F. Robertson, Greed. Gut Feelings, Growth, and History, Polity Press, Cambridge 2001,

${ }^{20}$ L.L. Hansen, S. Movahedi, Wall Street Scandals. The Myth of Individual Greed, „Sociological Forum" 2010, vol. 25, no. 2, June. 
słowy, co mają na myśli ci, którzy dzisiaj mówią o chciwości. I nie chodzi o odkrycie czegoś, co przypominałoby grawitację, której podlegają wszystkie ciała na powierzchni Ziemi. Raczej o społeczne uwarunkowania tego, co się stało, a także o znaczenie słowa "chciwość" w tych dyskusjach nad źródłami kryzysu.

Mówiąc o mechanizmach, nie sposób nie widzieć związku tego, o czym mówimy, z pojęciem rynku jako formy żywiołowej koordynacji działań jednostek. Nie jest to jednak obszar pozakulturowy i - niczym procesy przyrodnicze - poza skuteczną kontrolą zorganizowanych grup ludzkich. Neil Fligstein traktuje rynki jako twory polityczno-kulturowe ${ }^{21}$. Przedsiębiorcy, menedżerowie, szeregowi pracownicy zawsze działają $\mathrm{w}$ pewnym otoczeniu społecznym, którego wpływ odczuwają. Firmy, dla których zawsze liczy się stabilność, oczekują określonych działań od rządów, parlamentów i wymiaru sprawiedliwości, bowiem od tych władz zależy "architektura rynków”. Koncepcję tę zastosował Fligstein do analiz kryzysu na amerykańskim rynku kredytów hipotecznych, od którego zaczęło się to globalne zamieszanie, którego skutki odczuwamy wszyscy do dzisiaje22.

Nie trzeba nikogo przekonywać co do tego, że własne mieszkanie lub dom nie tylko są marzeniem ludzi, którzy ich nie posiadają, ale też ciągłym wyzwaniem dla polityków, którzy lubią obiecywać wyborcom spełnienie ich marzeń. Własny dom to podstawowy składnik zwłaszcza „amerykańskiego marzenia". W połowie ubiegłego stulecia Amerykanin znajdował dom, który był akurat na sprzedaż, szedł do banku i po przedstawieniu stosownych zaświadczeń (zwłaszcza o zarobkach) otrzymywał kredyt hipoteczny, np. na trzydzieści lat. Spłacając kredyty, on i ogromna liczba jemu podobnych zasilali bank w gotówkę, która umożliwiała udzielanie dalszych kredytów. W razie niewypłacalności dłużnika bank eksmitował mieszkańców i przejmował nieruchomość, którą mógł sprzedać i odzyskać wyłożone pieniądze.

Nowy system, który pod koniec XX wieku zdominował rynek nieruchomości, był bardziej wydajny, bowiem generował większą ilość pieniądza, który mógł być przeznaczony na kredyty mieszkaniowe. Bank nie czekał na spłatę kredytu przez dłużnika, lecz odsprzedawał wierzytelności, co umożliwiało dalsze udzielanie kredytów hipotecznych. Tzw. sekurytyzacja była zamianą wierzytelności na papiery wartościowe, których sprzedaż oznaczała zbycie przyszłych należności z tytułu udzielonego kredytu (zresztą nie tylko hipotecznego). Bank stawał się $\mathrm{w}$ ten sposób pierwszym ogniwem

${ }^{21}$ N. Fligstein, The Architecture of Markets. An Economic Sociology of the Twenty-first-century Capitalist Societies, Princeton University Press, Princeton 1996.

${ }^{22}$ N. Fligstein, A. Goldstein, The Anatomy of the Mortgage Securitization Crisis, [w:] Markets on Trial, eds M. Lounsbury, P.M. Hirsch, Emerald, Bingley 2010. 
w całym łańcuchu organizacji, który łączył kredytobiorcę z rynkami finansowymi. Kredyty hipoteczne były zabezpieczeniem obligacji sprzedawanych na całym świecie (MBS - mortgage backed securities). Same te obligacje w ramach specjalnych funduszy - mogły znowu być zabezpieczeniem kolejnych obligacji - jeszcze bardziej „oddalonych" od pierwotnych kredytobiorców.

Sekurytyzacja znana była już pod koniec XIX wieku i dopiero Wielki Kryzys zakończył pierwszy etap rozwoju tego typu innowacji finansowych. Jednocześnie właśnie w latach trzydziestych XX wieku rząd federalny zaczął angażować się we wspieranie rynku kredytów hipotecznych. Z kolei w latach sześćdziesiątych narastały obawy przed nadmiernym powiększaniem deficytu budżetowego i rząd nie mógł bezpośrednio finansować akcji kredytowych. Mógł jednak wspierać organizacje zajmujące się udzielaniem kredytów hipotecznych poprzez objęcie ich swoimi gwarancjami. Ten polityczny wymiar całego procesu był właśnie takim elementem tworzenia architektury rynku, o którym pisał Fligstein. Warto pamiętać, że to rząd ratował firmy i banki „,zbyt duże, żeby upaść” w latach 2007-2008.

Dlaczego jednak doszło do kryzysu? Początkiem całego łańcucha sekurytyzacji był zawsze indywidualny kredytobiorca. Popyt na obligacje zabezpieczane kredytami hipotecznymi był ogromny, i to na całym świecie. W pewnym sensie uruchomiona machina funkcjonowała zbyt dobrze, bowiem już w 2004 roku zaczęło brakować kredytobiorców posiadających tradycyjnie rozumianą zdolność kredytową (stała praca, wkład własny, brak przypadków niewypłacalności w przeszłości). Firmy pożyczkowe oraz banki udzielające kredytów zdecydowały się złagodzić swoje wymagania i udzielać kredytów osobom, które w przeszłości nigdy by ich nie dostały (kredyty niekonwencjonalne - subprime). Wzrastało ryzyko, którym jednak nie przejmowano się $\mathrm{w}$ sytuacji, gdy ceny nieruchomości stale rosły. Bank zawsze mógł odzyskać swoje pieniądze. Ponadto nowatorskie instrumenty finansowe potrafiły przekształcić ryzykowne kredyty w pozornie pozbawione ryzyka i wysoko oceniane przez agencje ratingowe papiery wartościowe, chętnie kupowane na całym świecie. Gdy bańka na rynku mieszkaniowym pękła i ceny domów zaczęły spadać, a skomplikowane instrumenty finansowe straciły swoje wsparcie z powodu niewypłacalności dłużników, którzy stanowili podstawę całej piramidy, tylko interwencja rządu federalnego uchroniła światowy system finansowy przed kompletnym załamaniem. Pytanie, które nas tutaj interesuje, brzmi zatem, w którym momencie można mówić o potocznie rozumianej chciwości jako przyczynie kryzysu23.

${ }^{23}$ Odpowiadając na to pytanie, czerpię z N. Fligstein, A. Goldstein, op. cit., oraz z R.T. Miller, Morals in a Market Bubble, „University of Dayton Law Review” 2009, vol. 35, no. 1, Fall (portal Social Science Research Network), http:/ / ssrn.com [dostęp: 12.04.2014]. 
Początkiem całego łańcucha są oczywiście klienci firm pożyczkowych i banków, którzy wiedząc, że ceny nieruchomości cały czas rosną - chętnie ulegali namowom urzędników oferujących im kredyt, nie zważając na fakt, że ówczesne ich zarobki nie pozwalały na spłatę tego zadłużenia. Sądzili jednak, iż za rok lub dwa wartość kupionej nieruchomości wzrośnie na tyle, że będzie możliwa sprzedaż domu lub zaciągnięcie nowego kredytu pod zastaw tej nieruchomości i łatwa spłata kredytu pierwotnego. A zatem wiele z tych osób brało kredyty w celach spekulacyjnych (często nawet kilka, aby kupić większą liczbę domów). Czy możemy mówić tutaj o nadmiernym pożądaniu bogactwa? Czy ci klienci, pomnażając majątki w okresie boomu, odbierali innym szanse na bogacenie się? Zdecydowanie nie, bowiem ich działania nakręcały jeszcze bardziej spiralę wzrostu cen nieruchomości. Podstawowa przesłanka uznania ich działań za "grzeszne", czyli bogacenie się kosztem innych, tutaj nie zachodzi. W szczególności nie dotyczy to mniejszości etnicznych, dla których liberalizacja zasad udzielania kredytów była szansą na pierwszy własny dom i - popieraną przez polityków - stabilizację za sprawą spełnienia się amerykańskiego marzenia.

Amerykańscy konsumenci pod koniec XX wieku dawno już przestali oszczędzać i nastawili się na wydawanie. Po II wojnie światowej przeciętne gospodarstwo domowe utrzymywało swoje zadłużenie na poziomie $20 \%$ własnych dochodów. W okresie boomu mieszkaniowego zadłużenie przekraczało o jedną trzecią ich zarobki24. Mamy więc do czynienia z zasadniczą zmianą kulturową, której podporządkowany był styl życia przeciętnej rodziny. Oczywiście, ktoś musiał finansować tę konsumpcję, czyli kupować zabezpieczone kredytem hipotecznym obligacje, ktoś zazwyczaj dysponujący nadmiarem gotówki. W przeważającej mierze były to Chiny, które produkowały większość tanich i masowo kupowanych w Europie i Stanach Zjednoczonych produktów.

Czy można mówić o chciwości inwestorów? Raczej nie. Rząd Chin postępował roztropnie, inwestując $w$ amerykańskie obligacje państwowe i prywatne. Trudno tu mówić o zabieraniu innym (chyba że mamy na myśli zabieranie innym pracy, ale to już inna historia). Władze Narwiku, które pożyczone $\mathrm{w}$ banku pieniądze zainwestowały $\mathrm{w}$ egzotyczne dla nich instrumenty finansowe, nie robiły tego dla siebie, lecz z myślą o miejskich inwestycjach, które miały służyć wszystkim. Nie ma tu żadnej chciwości, lecz jedynie brak rozwagi ${ }^{25}$.

24 R. Lowenstein, The End of Wall Street, Penguin Press, New York 2010, s. 3.

${ }^{25}$ House of cards, scen. i prod. J. Jacoby, CNBC, Inc. 2009 (film dokumentalny emitowany przez CNBC Europe oraz dostępny w Internecie). 
Czy firmy pożyczkowe namawiające klientów do zaciągania kredytów odznaczały się chciwością? Do pewnego stopnia. Często proceder ten graniczył z przestępstwem: urzędnicy gonili za prowizją, właściciele tych firm zarabiali miliony. Niemniej wszystko odbywało się zgodnie z prawem, a co więcej, włączanie mniejszości etnicznych do grupy posiadaczy domów mogło uchodzić za pracę na rzecz demokratyzacji kapitalizmu i stworzenia „społeczeństwa właścicieli”, czyli coś pochwalanego przez polityków na każdym szczeblu oraz opinię publiczną. Angelo Mozilo, współtwórca Countrywide (jednej z takich firm), syn włoskiego imigranta, uważał, że każdy obywatel ma prawo do kredytu. Wiedział jednocześnie, iż trzeba podretuszować dokumentację kredytową, np. w zakresie zarobków (często nieistniejących), jednak rosnące ceny nieruchomości stanowiły rodzaj zabezpieczenia przed stratami firmy $\mathrm{w}$ razie niewypłacalności dłużnika. Jak pisał Roger Lowenstein, łatwy kredyt usprawiedliwiany wizją refinansowania przypominał piramidę finansową Ponziego: stare kredyty miały być spłacane nie z zarobków kredytobiorców, lecz dzięki nowym kredytom ${ }^{26}$.

Czy banki dokonujące wielopiętrowej często sekurytyzacji kredytów hipotecznych były chciwe? Czy odebrały komuś należną mu część zysków? Można powiedzieć, że starały się zaspokoić globalny popyt na obligacje zabezpieczane hipotecznie, a także korzystały $\mathrm{z}$ niskich stóp procentowych. Uprzedzając zarzut, iż wykorzystywały naiwność inwestorów, powiedzieć należy, że często występowały zarówno w roli emitentów, jak i inwestorów, zachowując emitowane papiery dla siebie. Nie ma sensu nazywać tego typu logiki chciwością, chyba że każdą działalność zarobkową banków określimy $\mathrm{w}$ ten sposób. Wrócilibyśmy jednak do światopoglądu średniowiecznego potępiającego pożyczanie pieniędzy na procent. W ostatecznym rozrachunku firmy te ukarały same siebie. Dobrze obrazuje to znany film zatytułowany w oryginale Margin call, co oznacza konieczność zbilansowania rachunku inwestycyjnego i wezwanie do uzupełnienia środków. Można by to przetłumaczyć na przykład jako „Rozliczmy się" lub „Czas rozliczeń". Łatwiej jednak było sięgnąć po słowo powszechnie zrozumiałe i nadać filmowi tytuł Chciwość, pod jakim był wyświetlany w Polsce.

Paradoksalnie, najtrudniej byłoby zarzucać chciwość regulatorom, z Alanem Greenspanem na czele, których zadaniem było czuwać nad funkcjonowaniem amerykańskiej gospodarki, a w szczególności rynków finansowych. Ich neoliberalne poglądy pozwalały na ignorowanie niepokojących sygnałów i umacniały wiarę w samoregulacyjny potencjał rynku. Greenspan wielokrotnie podkreślał, że bardzo trudno określić, czy mamy do czynienia

${ }^{26}$ R. Lowenstein, op. cit., s. 17, 31, 34. 
z bańką spekulacyjną wtedy, gdy ona się tworzy. (Nie mówiąc już o tym, iż ktoś mógłby pozwolić sobie na przekłucie jej). Dopiero gdy rynek dokonuje korekty - wszyscy wiedzą, co się stało27. Można zarzucać regulatorom wiele rzeczy, przede wszystkim ideologiczne zaślepienie, jednak nadmierna żądza posiadania nie mogła być ich podstawową motywacją. Twierdzi się, że źródła kryzysu mają charakter systemowy. Co to jednak znaczy? O jakie powiązania poszczególnych elementów może chodzić? Szczególną uwagę warto zwrócić na związki Wall Street z rządem federalnym, bankierów z politykami. To także może tłumaczyć pasywną rolę regulatorów oraz poczucie bezkarności wielu przedstawicieli nowojorskiej finansjery, a dokładniej: przekonanie, iż dysponują rodzajem przyzwolenia na ryzyko. Poczucie władzy dodawało im odwagi. Przykładem może być kariera Jona Corzine'a, prezesa banku Goldman Sachs, następnie senatora oraz gubernatora stanu New Jersey i wreszcie ponownie prezesa firmy MF Global, którą jednak doprowadził do bankructwa w 2011 roku2 ${ }^{28}$. Jay Richards twierdził, że to nie chciwość, lecz kolesiostwo (cronyism) przyczyniło się do kryzysu finansowego ${ }^{29}$. John Allison wprost obwinia interwencje rządu i związane $\mathrm{z}$ nim organizacje: nie tyle rynek zawiódł, ile właśnie rząd rynkiem manipulujący. Politycy powoływali się na „wolny” rynek, lecz jednocześnie go współtworzyli30.

Ciekawe światło na problem chciwości w dobie kryzysu rzucają opracowania Steve'a Suranovica ${ }^{31}$. Twierdzi on, że chciwość rzeczywiście istnieje, jednak obok swojego przeciwieństwa - dobroczynności, dzielenia się z innymi. Chciwość definiuje esencjalistycznie jako żądzę bogactwa, lecz jednocześnie uważa, iż społeczna ocena tego zjawiska zależy od okoliczności, czyli od tego, czy mamy do czynienia z wymianą dobrowolną czy niedobrowolną, z uczciwą transakcją handlową czy kradzieżą. Przedsiębiorca, bogacąc się dzięki ciężkiej pracy i oferowaniu produktu, który zaspokaja ludzkie potrzeby, byłby chciwy $\mathrm{w}$ dobrym sensie, niebudzącym niczyjego sprzeciwu. Bogacąc się kosztem innych, okradając ich, nie uzyska jednak rozgrzeszenia ze strony tych, których zmusza do niechcianej wymiany.

27 Ibidem, s. 7.

${ }^{28}$ M. Kolakowski, Jon Corzine, http:/ / financecareers.about.com [dostęp: 1.03.2014].

${ }^{29}$ Jego poglądy prezentuje T. O'Neil, Christian Scholar: Financial Crisis Caused by 'Cronyism' More Than Greed, „The Christian Post” 18.08.2013, www.christianpost.com [dostęp: 12.03.2014].

30 Prace J.A. Allisona The Financial Crisis and the Free Market Cure (2013) omawia R.M. Salsman, The Financial Crisis Was a Failure of Government, Not Free Market, „Forbes” 19.09.2013, www.forbes.com [dostęp: 25.04.2014].

31 S. Suranovic, Greed, Capitalism and the Financial Crisis, Working paper IIEP-WP-2010-22, Institute for the International Economic Policy, The George Washington University, Washington 2010, www.gwu.edu/ iiep [dostęp: 22.11.2013]. 
Suranovic, rozróżniając dobrą i złą chciwość, popełnia - moim zdaniem błąd polegający na tym, że zakłada ponadhistoryczną charakterystykę określonego zjawiska opartą na rozpoznaniu natury ludzkiej (imperfect being). Niemniej wnioski, do których dochodzi - wbrew swojej oczywistości - są bardzo ciekawe. „Dobra chciwość” nie budzi sprzeciwu, jest podstawą przedsiębiorczości, ciężkiej pracy, ambicji w dążeniu do celu itd. Społeczeństwo potępia chciwość zmuszającą ludzi do niedobrowolnej wymiany, w efekcie której czują się okradani. Przeciętny podatnik amerykański nie miał wpływu na rozwój wydarzeń, które doprowadziły do załamania rynków finansowych (dodałbym: nawet jeśli wziął kredyt hipoteczny w celach spekulacyjnych). Wpływ miały natomiast ryzykowne operacje banków i innych firm, które liczyły na wsparcie przychylnego im rządu (zawsze za pieniądze podatnika) i które były świadectwem zjawiska nazywanego pokusą nadużyć (moral hazard): skoro jesteśmy tacy duzi, rząd nie pozwoli nam upaść. Stąd też bierze się znane hasło krytyków polityki ratowania prywatnych firm przez państwo: prywatyzacja zysków - nacjonalizacja strat.

Nie warto jednak - moim zdaniem - mówić o konstruktywnej czy dobrej chciwości. Pojęcie to pochodzi z innej epoki, w której pojęcie grzechu pełniło istotne funkcje kontrolne w społeczeństwie. Grzech rzeczywiście wykluczał. Dzisiaj grzech nie wyklucza - czyni to udowodnione przestępstwo pociągające za sobą karę, a zatem prawo ma tutaj najwięcej do powiedzenia. Dzisiaj słowo "chciwość" ma piętnować działalność przestępczą, aczkolwiek nie wszyscy przekonani o kryminalnych źródłach kryzysu używają tego słowa. Co jednak oznacza to słowo w 2014 roku? Dlaczego jest tak popularne? Czemu służy? Czy pewnej opowieści z morałem?

\section{CO „CHCIWOŚĆ" ZNACZY DZISIAJ?}

W antyku i średniowieczu chciwy był bogacz, bowiem to on zabierał cały plon, nie zostawiając innym zbyt wiele. Dzisiaj, gdy myślimy o gospodarce $w$ innych kategoriach (gra o sumie dodatniej), bohaterem, i to raczej pozytywnym, jest przedsiębiorca, a nie człowiek bogaty. Oczywiście, zdarza się, że ktoś odbiera coś innym, okrada ich, oszukuje. Nieuczciwość w biznesie zazwyczaj polega na tym, iż ktoś inny traci. Oszustwo zamienia kapitalizm $\mathrm{w}$ lokalną grę o sumie zerowej: $\mathrm{w}$ danym momencie, na określonym rynku moja wygrana to twoja strata. Moja firma powinna zutylizować przeterminowane wędliny (czyli musiałaby ponieść stratę - co się zdarza w gospodarce często), jednakże decyduję się na ich obmycie i ponowne zapakowanie, lecz już z nową datą ważności. Moja firma wśród swoich aktywów posiada 
zbyt dużo „toksycznych” papierów wartościowych - trzeba więc kogoś namówić, aby je od nas kupił32. Stratę - $\mathrm{w}$ takiej lub innej postaci - poniesie kupujący. Skąd biorą się takie zachowania?

Esencjalistyczne myślenie zakłada, że taka jest natura ludzka (np. z gruntu egoistyczna, jak u Hobbesa czy Hume'a). Jeżeli jednak tak jest - przyczyna, która stale występuje, nie tłumaczy konkretnych skutków. Dlaczego tym razem właśnie chciwość miałaby doprowadzić do kryzysu?33 Jeżeli jednak odrzucimy to ponadczasowe rozpoznanie natury ludzkiej i prowadzimy analizy systemowe, wyłania się całkiem inny obraz. Uwarunkowania systemowe mogą "zachęcać" jednostki do określonych zachowań, mogą umacniać pewne postawy, upowszechniać motywacje. „Wszyscy tak robią - mnie też się uda. Kto nie ryzykuje, ten nic nie osiągnie". Thomas Donaldson pisze w tym kontekście o spowszednieniu wątpliwych moralnie zachowań (normalization of questionable behavior). Dodaje jednak słusznie, że firma, która chciałaby roztropnie wycofać się z tego wyścigu, naraziłaby się na duże straty, przynajmniej w krótkim okresie. To miał na myśli Chuck Prince, gdy wygłaszał słynne już zdanie: „Dopóki muzyka gra, należy wstać i tańczyć”. Twierdząc, iż chciwość niewiele nam wytłumaczy z tego, co się stało, Donaldson słusznie twierdzi, że "chciwość zależy raczej od okazji oraz racjonalizacji”"34. Innymi słowy, nie można nie zauważać, iż uwarunkowania systemowe wytwarzają określone subiektywne struktury, czyli, w sumie, rozumowania indywidualnych podmiotów.

Karen Ho powiada: „Kryzys z 2007 roku był dzieckiem kultury Wall Street". Nie tworzą jej źli (chciwi) bankierzy, lecz proces socjalizacji, który w taki sposób od początku kariery ich kształtuje. Liczy się spryt (smartness): charakteryzuje się on "agresywnością i determinacją, chociażby do tego, żeby pracować od 9 rano do $1 \mathrm{w}$ nocy siedem dni w tygodniu i spać pod własnym biurkiem"35. Dużo wiemy o tego rodzaju sprycie chociażby w związku z upadkiem Enronu, czemu poświęcono wiele opracowań, m.in. pracę The Smartest Guys in the Room ${ }^{36}$. I w tym przypadku słowo "chciwość" pojawiało się bardzo często. Nie da się jednak wyjaśnić przyczyn upadku tej

\footnotetext{
$32 \mathrm{O}$ takie praktyki oskarżał własnego pracodawcę Greg Smith, Why I Am Leaving Goldman Sachs, „The New York Times” 14.03.2012, www.nytimes.com [dostęp: 14.12.2013].

33 A. Argandoña, Three Ethical Dimensions of the Financial Crisis, Working paper WP-944, IESE Business School, University of Navarra, Pamplona 2012, January, s. 4.

34 T. Donaldson, Three Ethical Roots of the Economic Crisis, ,"Journal of Business Ethics" 2012, vol. 106 , no. 1 , s. 8 .

35 Wywiad Aleksandry Kaniewskiej z Karen Ho (autorką Liquidated. An Ethnography of Wall Street), Antropolog na Wall Street, Instytut Obywatelski, www.instytutobywatelski.pl [dostęp: 12.12.2013].

36 B. McLean, P. Elkind, The Smartest Guys in the Room. The Amazing Rise and Scandalous Fall of Enron, Portfolio, London 2003.
} 
firmy bez wskazania na kulturę organizacyjną, w ramach której odnaleźć można prawdziwą mieszankę wybuchową: wartością najwyższą był wysoki poziom adrenaliny, skłonność do ryzyka, seks w miejscu pracy oraz sporty ekstremalne jako forma odreagowania stresu, a jednocześnie panował kult ryzyka i wyczynu za wszelką cenę.

W okresie przed kryzysem 2007-2009 istniała także specyficzna kultura Wall Street. Podkreśla się często jego bliskie powiązania ze światem polityki i władzą zarówno wykonawczą, jak i ustawodawczą, co dawało poczucie siły i - czasami - bezkarności. Zniesienie ustawy Glass-Steagall z 1933 roku, zakazującej łączenia tradycyjnej działalności bankowej z bankowością inwestycyjną, było rezultatem lobbingu przedsiębiorców i bankierów. Z kolei wielu polityków i funkcjonariuszy państwowych miało swoje korzenie na Wall Street. Alan Greenspan, Arthur Levitt (szef SEC) oraz Robert Rubin i Henry Paulson (Sekretarze Skarbu) byli tego najlepszymi przykładami. Socjologowie mówiliby tutaj o oddziaływaniach środowiskowych i wzajemnych powiązaniach (social networks). Regulatorzy rynków finansowych, którzy przymykali oczy na wiele nieprawidłowości, robili to nie dlatego, że nie rozumieli pewnych mechanizmów, lecz raczej z tego powodu, iż rozumieli Wall Street zbyt dobrze. I nawet jeśli głosili skrajnie wolnorynkowe poglądy i nie byli skłonni do ingerencji - byli jednak architektami tego rynku.

A zatem chciwość, ahistorycznie rozumiana, nie na wiele się przydaje, jeżeli szukamy przyczyn kryzysu. Powtórzmy: stale występująca przyczyna nie tłumaczy konkretnego, usytuowanego w czasie skutku. Steve Suranovic twierdzi, że nie warto demonizować chciwości - ja dodałbym, iż nie warto także jej esencjalizować. Ponadto trzeba też odróżniać racjonalność ekonomiczną (kupować tanio - sprzedawać drogo) od zachłanności i myślenia $\mathrm{w}$ kategoriach krótkoterminowych - $\mathrm{w}$ gruncie rzeczy szkodliwych dla przedsiębiorstwa i jego właścicieli. W przeciwnym razie oznaczałoby to, że sama racjonalność ekonomiczna i wszelka kalkulacja kosztów i korzyści bliska byłaby chciwości, która w ten sposób stawałaby się elementem definiującym sam kapitalizm.

Takie poglądy zdaje się głosić Alasdair MacIntyre, a jego wykład na temat kryzysu finansowego, wygłoszony w Cambridge w 2010 roku, potwierdza to. Chciwi finansiści starają się przerzucić jak najwięcej ryzyka na innych, kryzysy są w związku z tym nieuchronne, podobnie jak pogłębiające się nierówności społeczne. Chciwość staje się ponadto zjawiskiem masowym, bowiem zachęcani do konsumpcji ponad stan ludzie rzeczywiście gotowi są zadłużać się, aby posiadać coraz więcej dóbr ${ }^{37}$. Swoją książkę

37 J. Cornwell, MacIntyre on Money, „Prospect” 20.10.2010, www.prospectmagazine.co.uk [dostęp: 1.02.2014]; R.T. Miller, Waiting for St. Vladimir, „First Things” 2011, no. 1, www.first things.com [dostęp: 28.02.2014]. 
Dziedzictwo cnoty, podstawowy wykład jego poglądów sprzed ponad trzydziestu lat, filozof kończy porównaniem z upadającym imperium rzymskim, przy czym barbarzyńcy nie czekają u wrót, lecz już władają światem zachodnim, aczkolwiek nie wszyscy zdają sobie z tego sprawę ${ }^{38}$. Nie sposób w tym miejscu polemizować z wizją MacIntyre'a (rzecz wymagałaby osobnego opracowania), lecz warto zauważyć, że pojęcie chciwości jako grzechu, a także pojęcie cnoty służą zakwestionowaniu samych podstaw nowożytnej formy gospodarki: uwiąd cnót oraz dominacja grzechu czyni kapitalizm instytucją z samej swojej natury wadliwą.

Dzisiaj taką schyłkową wizję prezentuje Martin Scorsese w swoim filmie Wilk $z$ Wall Street. Widzimy świat pogrążony $\mathrm{w}$ grzechu, a nagromadzenie jego przejawów przypomina wręcz biblijne obrazy upadku. Nie pokazuje się tu ludzi, których główni bohaterowie oszukali, nie ma mowy o ofiarach i kosztach społecznych, chociaż dzieło jest artystycznym komentarzem do niedawnego kryzysu w świecie finansów. Zamiast tego film Scorsesego epatuje obrazami orgii i wymyślnych rozrywek odmalowanymi bardzo realistycznie. Gdy wyświetlany był na Wall Street, wzbudzał okrzyki zachwytu i aprobaty ${ }^{39}$. Z drugiej strony, czy można się było spodziewać innych widzów? Także poza Wall Street na przeciętnego widza działają już tylko mocne sceny, obrazy walki i przemocy, a w kwestiach obyczajowych coraz śmielsze ujęcia, na granicy pornografii. Obraz rozpadu pewnego świata ma przerażać, ale i ekscytować. Nie można zapominać o tym, że to nie żądze kapitalistów tworzą dzisiejszy kapitalizm. Raczej żądze mas - aczkolwiek podsycane przez marketing wielkich firm oraz przekaz medialny. Nie chodzi jedynie o żądzę pieniądza, ale także o inne grzechy, np. obżarstwo. Czy nadmierna konsumpcja hamburgerów napędzana jest nieposkromioną żądzą, czy też wspomniany grzech jest konsekwencją młodzieżowej kultury szybkich dań?

Kultura współczesna „zapomniała”, czym jest grzech, a jednocześnie oferuje jego wizerunki $w$ mediach. Sceny moralnego upadku przyciągają widzów. Od 2007 roku rekordy oglądalności bije wyświetlany w Stanach Zjednoczonych dokumentalny serial telewizji CNBC American Greed poświęcony największym oszustwom, nie tylko gospodarczym. Książki napisane przez skruszonych grzeszników sprzedają się w dużych nakładach (Geraint Anderson, Greg Smith czy w końcu sam Jordan Belfort, ów „wilk z WS”).

38 A. MacIntyre, After Virtue. A Study in Moral Theory, Duckworth, London 1981, s. 245. Wydanie polskie: A. MacIntyre, Dziedzictwo cnoty. Studium z teorii moralności, przeł. A. Chmielewski, PWN, Warszawa 1996.

${ }^{39}$ R. Syme, The Great Fratsby, "The New Yorker" 28.12.2013, www.newyorker.com [dostęp: 1.04.2014]. 
Pojęcie "chciwości" ma oczywiście piętnować, trudno jednak powiedzieć, czy obrazy zła skutecznie odstraszają i wychowują. W średniowieczu pojęcie grzechu miało dyscyplinować, socjalizować pożądanie. Dzisiejsza socjalizacja wspiera raczej uwalnianie osobowości, dążenie do autentyczności i intensyfikację doznań. Dwanaście lat temu Brian McNair pisał o demokratyzacji pożądania, mając na myśli łatwy dostęp do pornografii, aluzje do niej zawarte $\mathrm{w}$ reklamie, a także związane $\mathrm{z}$ seksualnością przemiany obyczajowe i ich wizerunki medialne ${ }^{40}$. Dzisiaj powiemy już więcej: demokratyzacja pożądania dotyczyć może wszelkich żądzy i jak „prawdziwa” demokracja opiera się na mediach.

Być może społeczeństwo konsumpcyjne nie zasługuje na przypisywanie jego członkom chciwości, bowiem pożądanie pewnego nadmiaru nie jest aberracją, lecz obowiązującym trendem. Nie chodzi przy tym o posiadanie dużej ilości ubrań, lecz o noszenie ubrań modnych. Kupuje się zatem nie tyle rzeczy, ile doznania, wartości symboliczne; Swatch nie ma mierzyć czasu, lecz coś wyrażać. Paradoksalnie, nie dominuje „mieć”, lecz „być”, bowiem marki współtworzą tożsamość swoich wyznawców. Trudno też byłoby twierdzić, że masowa konsumpcja opiera się na masowej chciwości - cóż bowiem za znaczenie miałaby "chciwość” w tym zestawieniu? Kupujący nie odbierają nikomu środków do życia. Przeciwnie, bez ich konsumpcji stanęłaby gospodarka.

Paradoksalnie zatem, dzisiaj pojęcie chciwości, wyjęte z pierwotnego religijnego kontekstu, nie piętnuje, lecz fascynuje, jest modnym tematem. Demokratyzacja pożądania zakłada apel do indywidualnych pragnień, pobudzanie ich i podtrzymywanie, co jest istotnym elementem kultury popularnej. Oczywiście, zawsze pojęcie to może być użyte w dawnym znaczeniu, gdy chce się wyrazić sprzeciw lub oburzenie. Nie pomaga jednak w zrozumieniu współczesnych zjawisk, szczególnie gospodarczych.

Parafrazując słowa znanej piosenki, można by powiedzieć, że „chciwość tak pięknie tłumaczy...". Być może pięknie - lecz nieprecyzyjnie.

\section{BIBLIOGRAFIA}

Argandoña A., Three Ethical Dimensions of the Financial Crisis, Working paper WP-944, IESE Business School, University of Navarra, Pamplona 2012, January. Asnyk A., Poezje, t. 1, Nasza Księgarnia, Warszawa 1938.

40 B. McNair, Seks, demokratyzacja pożądania i media, czyli kultura obnażania, przeł. E. Klekot, MUZA SA, Warszawa 2004, s. 30. 
Barker C., Studia kulturowe. Teoria i praktyka, Wydawnictwo Uniwersytetu Jagiellońskiego, Kraków 2005.

Collins English Dictionary, Harper Collins Publisher, Glasgow 1991.

Cornwell J., MacIntyre on Money, „Prospect” 20.10.2010, www.prospectmagazine.co.uk [dostęp: 1.02.2014].

Donaldson T., Three Ethical Roots of the Economic Crisis, "Journal of Business Ethics" 2012, vol. 106, no. 1 .

Fligstein N., The Architecture of Markets. An Economic Sociology of the Twenty-first-century Capitalist Societies, Princeton University Press, Princeton 1996.

Fligstein N., Goldstein A., The Anatomy of the Mortgage Securitization Crisis, [w:] Markets on Trial, eds M. Lounsbury, P.M. Hirsch, Emerald, Bingley 2010.

Greene B., Million Idea. Use Greed for Good, "Chicago Tribune" 15.12.1986, http:/ / articles.chicagotrubune.com [dostęp: 15.05.2014].

Hansen L.L., Movahedi S., Wall Street Scandals. The Myth of Individual Greed, „Sociological Forum" 2010, vol. 25, no. 2, June.

Iwaszkiewicz J., Nowa miłość, Czytelnik, Warszawa 1947.

Kaniewska A., Antropolog na Wall Street, wywiad z Karen Ho, Instytut Obywatelski, www.instytutobywatelski.pl [dostęp: 12.12.2013].

Kolakowski M., Jon Corzine, http:/ / financecareers.about.com [dostęp: 1.03.2014].

Lam J., Wybór pism, t. 1, Głowy do pozłoty, Redakcja Gazety Polskiej, Warszawa 1899.

Lowenstein R., The End of Wall Street, Penguin Press, New York 2010.

MacIntyre A., After Virtue. A Study in Moral Theory, Duckworth, London 1981, s. 245. Wydanie polskie: A. MacIntyre, Dziedzictwo cnoty. Studium z teorii moralności, przeł. A. Chmielewski, PWN, Warszawa 1996.

Mahoney J., Chrześcijaństwo a etyka przedsiębiorczości, [w:] Etyka w biznesie, red. P.M. Minus, Wydawnictwo Naukowe PWN, Warszawa 1995.

McLean B., Elkind P., The Smartest Guys in the Room. The Amazing Rise and Scandalous Fall of Enron, Portfolio, London 2003.

McNair B., Seks, demokratyzacja pożądania i media, czyli kultura obnażania, przeł. E. Klekot, MUZA SA, Warszawa 2004.

Miller R.T., Morals in a Market Bubble, "University of Dayton Law Review” 2009, vol. 35, no. 1, Fall (portal Social Science Research Network), http://ssrn.com [dostęp: 12.04.2014].

Miller R.T., Waiting for St. Vladimir, „First Things” 2011, no. 1, www.firstthings.com [dostęp: 28.02.2014].

Newhauser R., The Early History of Greed. The Sin of Avarice in Early Medieval Thought and Literature, Cambridge University Press, Cambridge 2000.

Newhauser R., The Seven Deadly Sins as Cultural Constructions in the Middle Ages, www.trinity.edu/rnewhaus/outline.html [dostęp: 1.03.2014].

O'Neil T., Christian Scholar: Financial Crisis Caused by 'Cronyism' More Than Greed, "The Christian Post" 18.08.2013, www.christianpost.com [dostęp: 12.03.2014].

Robertson A.F., Greed. Gut Feelings, Growth, and History, Polity Press, Cambridge 2001.

Salsman R.M., The Financial Crisis Was a Failure of Government, Not Free Market, "Forbes” 19.09.2013, www.forbes.com [dostęp: 25.04.2014].

Sen A., Czy pojęcie etyki biznesu ma sens ekonomiczny?, [w:] Etyka w biznesie, red. P.M. Minus, Wydawnictwo Naukowe PWN, Warszawa 1995.

Stownik jezzyka polskiego, t. 1, red. W. Doroszewski, Państwowe Wydawnictwo „Wiedza Powszechna", Warszawa 1958. 
Smith A., An Inquiry Into the Nature and Causes of the Wealth of Nations, [w:] Glasgow Edition of the Works and Correspondence of Adam Smith, eds R.H. Campbell, A.S. Skinner, Liberty Press, Indianapolis 1981.

Smith G., Why I Am Leaving Goldman Sachs, "The New York Times" 14.03.2012, www.nytimes.com [dostęp: 14.12.2013].

Suranovic S., Greed, Capitalism and the Financial Crisis, Working paper IIEP-WP-2010-22, Institute for the International Economic Policy, The George Washington University, Washington 2010, www.gwu.edu/ iiep [dostęp: 22.11.2013].

Syme R., The Great Fratsby, "The New Yorker" 28.12.2013, www.newyorker.com [dostęp: 1.04.2014].

Tickle P., Greed. The Seven Deadly Sins, Oxford University Press, Oxford 2004.

Wight J.B., Adam Smith and Greed, "Journal of Private Enterprise" 2005, vol. XIX, Fall.

Willett B., Financial Crisis Blaming the Culture of Greed?, "The Market Oracle" 7.04.2009, http:/www.marketoracle.co.uk [dostęp: 1.01.2014].

House of cards, scen. i prod. J. Jacoby, CNBC, Inc. 2009 (film dokumentalny emitowany przez CNBC Europe oraz dostępny w Internecie).

Wall Street, reż. O. Stone, scen. S. Weiser, O. Stone, Twentieth Century Fox, 1987. 